\title{
Tax aggressiveness determinants
}

\author{
Hani Werdi Apriyanti, ${ }^{1}$ Muhamad Arifin ${ }^{2}$
}

JIAFR | 27

\author{
1,2Universitas Islam Sultan Agung Semarang, Indonesia \\ email: hani.apriyanti@unissula.ac.id
}

\begin{abstract}
Purpose - This study aims to examine the effect of capital intensity, inventory intensity, corporate social responsibility and good corporate governance on tax aggressiveness. Good corporate governance variables used in this study were proxied with independent commissioners and auditcommitments.

Method - This research focused on manufacturing companies listed on the Indonesia Stock Exchange in the period of 2016-2018. 177 samples were collected using a purposive sampling technique from 59 companies over an observation period of 3 consecutive years. The samples were then analyzed using a multiple linear regression.

Result - The results of this study show that capital intensity has a positive and significant effect on tax aggressiveness, inventory intensity has a positive but not significant effect on tax aggressiveness, corporate social responsibility has no positive and significant effect on tax aggressiveness, Independent commissioner has a positive and significant effect on tax aggressiveness, and audit committee has a negative but significant effect on tax aggressiveness.

Implication - The results show that the company with high capital intensity tends to be more aggressive on tax. Therefore, the tax authorities must be aware to companies with these characteristics.

Originality - The addition of corporate social responsibility and good corporate governance as independent variables are thought to be related to the company's tax aggressiveness.
\end{abstract}

Keywords: company characteristics; corporate social responsibility; good corporate governance; tax aggressiveness 
Hani Werdi Apriyanti, Muhamad Arifin

\section{Introduction}

The function of taxes is to meet the needs of the state both in spending and as government policy in the social and economic aspects. Taxes are the

JIAFR | 28 largest sources of the state revenues. In the 2018 State Budget Posture, 85.4\% of the revenue came from the tax sector, while the rest was obtained from non-tax state revenue (PNPB) and grant income. The largest state revenue was from the tax revenue of IDR 1,618.1 trillion (www.kemenkeu, 2018). Taxes are still the largest sources of revenues used to finance the national development. Therefore, the government should improve the performance of tax revenues, so that the national development is not disrupted. The government should increase the tax ratio to maintain the country's ability to bear the payment of expenditures for the national development.

The tax ratio, or the comparison between tax revenue and gross domestic product, in Indonesia from 2015 to 2017, is still low. One factor determining the tax ratio is the compliance level. Low tax compliance in Indonesia has resulted in a low tax ratio. Therefore, the government is trying to improve the taxpayers' compliance so that the tax revenue performance can continuously increase. Government has made many efforts to improve the tax compliance. One of them is the difference in interests and perceptions between government as the tax authority and companies as the taxpayers. Taxpayers perceive tax obligations as expenses that will reduce income. Taxes are perceived by taxpayers as a burden that must be met which will reduce their net income (Nugraha \& Meiranto, 2015).

There is a tendency for companies to make various efforts aiming at reducing the tax burden. A motivation for reducing the tax burden is the goal to maximize the company profits. One of the companies' ways to maximize the corporate profits is through the tax planning (Jessica \& Toly, 2014). The company will plan the amount of tax paid within a period in various ways. If the tax burden to pay is large enough, the company will be more aggressive in doing tax planning. Companies become increasingly aggressive towards taxes because the large tax burden is perceived as a deduction for the company 
profits. This tax aggressiveness is usually performed by companies by exploiting the loopholes in the taxation regulations.

Tax aggressiveness practices are usually performed by utilizing the company's accounting policies. The company will use certain accounting methods to indirectly reduce the tax burden. This is related to the JIAFR | 29 characteristics of company, from the financial perspective, corporate social responsibility and corporate governance. Among the characteristics of the existing companies, capitals and assets, especially inventories, are closely related to expenses and profits obtained by the company. Therefore, planning for capital and inventory is one way that the companies can do related to their tax planning (Megarani, Warno \& Fauzi, 2019). Capital intensity and inventory can be a way to indirectly reduce the company's tax burden.

Capital intensity can be interpreted as a ratio involving the company ownership which is allocated in the form of fixed assets (Andhari and Sukartha, 2017). According to PSAK 16 (revised 2015) fixed assets are tangible assets owned to use in production, supply of goods or services, for leasing, or administrative purposes for more than one period. In accordance with the said PSAK, fixed assets are assets used for the company production to generate income.

In addition, the physical property, plant and equipment, according to PSAK have an economic life or are used for more than one period. The use of fixed assets with an economic life of more than one period will have an impact on the recognition of costs per period used by the company from the total costs attached to the asset. The company will recognize the depreciation expense for the use of asset. Companies with high fixed assets will be able to recognize their high depreciation expenses. This can be indicated from the company's aggressiveness towards taxes. With high capital intensity, it allows companies to recognize their high depreciation expenses. Corporate tax will be affected by depreciation expense caused by the ownership of fixed assets, because depreciation expense can reduce the tax expense (Imelia, 2015). The effect of intensity capital on tax aggressiveness has been investigated by various studies resulted in different findings from several researchers. 
Nugraha and Meiranto (2015) stated "capital intensity has a negative effect on tax aggressiveness". The findings of this study are different from those of research conducted by Mustika (2017) mentioning that capital intensity does not have an effect on tax aggressiveness. Meanwhile, the findings of research conducted by Andhari and Sukartha (2017) found that capital intensity can influence tax aggressiveness in a positive direction.

Companies can use the inventory on hand aiming at taking the advantages of the incurred costs in handling the inventory. With certain inventory intensity, the company can plan the amount of inventory costs as a deduction for revenue. Inventory intensity can be defined as the intensity (size) of inventory invested in the company. With high inventories, companies can recognize various kinds of costs related to the inventory management, such as maintenance, storage, supervision, and other costs. The higher the inventory, the higher the maintenance and storage expenses may be resulted, according to the inventory increase. The recognition of this expense will be one deduction for the company's profit. The company's profit will decrease with the expenses related to maintaining and storing these inventories, which will have an impact on the reduced amount of tax liabilities. Therefore, the tendency of companies to increase their inventory in the warehouse can be related to their aggressiveness towards taxes (Andhari \& Sukartha, 2017).

The effect of inventory intensity on tax aggressiveness has been investigated by several researchers and resulted in different findings. Andhari and Sukartha (2017) conducted a study finding that the results of inventory intensity had no effect on tax aggressiveness. The results of this study are different from those of research conducted by Adisamarta \& Noviari (2015) finding that there was a positive effect of inventory intensity on tax aggressiveness.

Tax aggressiveness is also associated with corporate social activities. Corporate Social Responsibility (CSR) is defined as the way a company manages a business both from the process and the obtained results, so that the process and results have a positive impact on society (Baker, 2003). CSR 
performed by the company is a form of social responsibility made by the company for public. In other words, companies performing CSR are socially responsible and negatively associated with the tax aggressiveness and perception that in earning profits, the companies do not commit fraud and tax evasion. Companies with high CSR will try to maintain a good reputation by not evading taxes. Tax aggressiveness can lead to the perceptions or bad signal for companies because companies are generally considered socially irresponsible (Freise et all, 2008). Tax aggressiveness causes a reduction in the state's income and impact on the society as a whole (Slemrod, 2004). Therefore, corporate tax aggressiveness is socially considered an irresponsible activity (Yoehana, 2014) .

The effect of CSR reporting practices on tax aggressiveness has been investigated by various researchers resulting in different findings. Davis et al. (2016), Zeng (2016), Lanis \& Richardson (2015), Huseynov \& Klamm (2012), and Kuriah \& Asyik (2016) expressed their opinion in the form of companies with less aggressive tax planning activities (tax avoidance) when compared to those with more aggressive tax and considered that those companies are more socially responsible (Watson, 2011). The results show that companies with good tax planning activities are those with good CSR performance. Hoi, Wu and Zhang (2013) and Watson (2015) have provided evidence that companies with low CSR activities tend to involve more aggressive tax avoidance policies.

In addition, tax aggressiveness is also related to corporate governance. Corporate governance includes both internal and external mechanisms. Several internal mechanisms in corporate governance are the independent board of commissioners and the audit committee (Agoes \& Ardana, 2013). The independent commissioner is an internal mechanism functioning as a supervisor in the company's activities. Meanwhile, the audit committee has the functions related to in the efficiency and effectiveness of company by producing financial reports free from the material misstatement. This mechanism is needed to provide protection for the shareholders (Putri, 
Hani Werdi Apriyanti, Muhamad Arifin

2014). The proxies of corporate governance used in this study are the proportion of independent commissioners and audit committee.

The independent board of commissioners necessarily made the JIAFR | 32 supervisory duties to minimize the agency conflicts between management and owners (Jensen \& Meckling, 1976; Khaoula \& Ali, 2012). An independent commissioner is needed to ensure the actions threatening the company's legitimacy are not implemented. Independent commissioners have implemented various mechanisms in performing their supervisory functions, both through regulating, controlling, and directing attitudes, behaviors, and management decisions and actions (Armstrong et al., 2015).

Research on the effect of corporate governance on tax aggressiveness has been previously investigated by some researchers. Lanis \& Richardson (2011), Khaoula \& Ali (2012), Chistiana \& Africano (2017) conducted the research on how corporate tax aggressiveness was influenced by independent commissioners. Christiana \& Africano (2017) found that companies with a large number of independent commissioners possibly influences tax aggressiveness and even reduces tax aggressiveness. Conversely, Khaoula and Ali (2012) said that there was no evidence that independent commissioners could influence corporate tax aggressiveness.

Meanwhile, Midiastuty and Suranta (2016) stated that the companies' audit committees must comply with the regulations including tax regulations because this is the duty and responsibility of audit committee. The number of audit committee in a company possibly reduces tax aggressiveness. Maharani and Suardana (2014) argued that the existence of an audit committee can affect the company's aggressiveness towards taxes. The company has considered that audit committee can supervise and influence the provision of more information related to the company's financial statements for the users.

Several researchers have conducted the research on corporate governance which can affect tax aggressiveness. Christiana and Africano (2017) conducted the research and found that corporate governance proxied by the audit committee has a positive effect on tax aggressiveness. 
Arismajayanti (2017) conducted the research and found that the audit committee did not affect tax aggressiveness. From the results of the previous research, there are still inconsistencies. Therefore, a further research is needed to strengthen the results of previous studies, and ensure the validity of research results on tax aggressiveness. This study was developed by Hidayat \& Fitria (2018) on the research entitled The effect of capital intensity, inventory intensity, profitability and leverage on tax aggressiveness. The difference between this study and the previous ones is related to the addition of corporate social responsibility and good corporate governance as independent variables (Abidin, Askandar \& Afifudin, 2018). Corporate social responsibility and good corporate governance are thought to be related to the tax aggressiveness of companies. This research was conducted on the manufacturing companies listed on the Indonesia Stock Exchange in a period of 2016-2018.

\section{Literature Review}

\section{Legitimacy Theory}

Legitimacy theory can be interpreted as a company operating system assisting the company to the surrounding environment (Gray et al., 1996). Companies made the social contracts in accordance with the prevailing values and norms to run in harmony. Legitimacy theory explains that a company will continue to strive in performing its operational activities to adjust with the norms prevailing in the society. The company tries to ensure that each operational activity performed is considered legitimate (Deegan, 2014). This is performed by the company to gain legitimacy from public related to its activities (Prasojo \& Syarifah, 2020).

Suryana (2011) stated that developments in the surrounding environment can affect the changes of company norms following the developments so that the existing norms can adapt to the society. Legitimacy theory states that companies are bound by contract with the society adjusting to the applicable norms and regulations in the society, and they must fulfill their obligations to the society. Legitimacy that must be fulfilled by the 
company is that related to the company's compliance with taxation obligations set by the government. This legitimacy is obtained by complying with the policies established by the government in accordance with applicable regulations.

Companies consistent and obedient in paying their taxes with the time and amount in accordance with government regulations without reduction or exaggeration are considered as the companies playing their role in social welfare and national development. The companies' participation in improving the community welfare and national development through the fulfillment of tax obligations will have a positive impact on the company since trusted by both public and government.

\section{Stakeholder theory}

Stakeholder theory states that companies operating to obtain profits can be distributed to all stakeholders (Chariri \& Ghozali, 2007). Stakeholder theory states that companies socially responsible for their business operations can have an impact on their stakeholders (Branco and Rodrigues, 2007). Based on stakeholder theory, the company is responsible not only to the company owner but also to external parties, such as the community, government, and other stakeholders. The government, including regulators, are corporate stakeholders, so the regulations set by the government must be implemented, one of which, through tax payments (Landolf, 2006) i.e. capital intensity and tax aggressiveness.

\section{Hypothesis Development}

\section{Capital Intensity and Tax Aggressiveness}

Capital intensity is an investment activity performed by companies in the form of fixed assets. Investment activities in the form of fixed assets can show the level of company efficiency in using assets to generate income. Fixed assets incur a depreciation expense as a deduction for income (Hanum, 2013). 
Andhari \& Sukartha (2017) stated that capital intensity positively affects tax aggressiveness. This proves that the company will be more aggressive towards its tax obligations when the company's capital intensity also increases. There is a unidirectional relationship of capital intensity with tax aggressiveness. If capital intensity increases, there will be an increase in aggressiveness of tax obligations. Investment in fixed assets is an option for companies to reduce profits through high depreciation expenses. According to the description, a hypothesis can be formulated as follows:

$H_{1}$ : Capital intensity has a positive effect on tax aggressiveness.

\section{Inventory Intensity and Tax Aggressiveness}

Inventory intensity can be defined as the amount of inventory invested by the company. The company's inventory count will determine the inventory maintenance expense. The more the amount of inventory, the greater the resulting maintenance burden and the more the storage load will increase. The company's profit will decrease due to the burden of maintenance and the supply storage, which will reduce the tax paid by increasing the inventory in the warehouse (Andhari \& Sukartha, 2017).

The research conducted by Adisamartha \& Noviari (2015) and Dwiyanti \& Jati (2019) has proven that inventory intensity positively affects tax aggressiveness. Companies in good inventory management will significantly affect cost efficiency due to the large number of supplies. The costs arising from the inventory management include those for materials, labor, storage, administration, and others such as sales. Companies with high inventories will become more aggressive on taxes because the company's profits in the current period are allocated to those in the future periods to reduce tax expenditures. Based on the description above, the hypothesis can be formulated as follows:

$\mathrm{H}_{2}: \quad$ Inventory intensity has a positive effect on tax aggressiveness. 


\section{Corporate Social Responsibility and Tax Aggressiveness}

Corporate Social Responsibility (CSR) is a social responsibility that must be performed by a company due to the impact caused by the company. JIAFR | 36 Companies have a social obligation to the society, and must ensure that they have a positive impact on the society. The expansion of social responsibility includes the responsibility of companies to properly pay the taxes to the Government in obtaining legitimacy from the public as the companies' social responsibility.

Kuriah \& Asyik (2016) and Nugraha \& Merianto (2015) state that corporate social responsibility negatively affects tax aggressiveness. The high level of CSR disclosure results in less tax aggressiveness because the company responsible to fulfill its obligations is to pay the taxes in accordance with the applicable regulations and not tax evasion (not tax aggressiveness). Based on the description above, the hypothesis can be formulated as follows:

$H_{3}$ : Corporate social responsibility has a positive effect on tax aggressiveness

\section{Independent Board of Commissioners and Tax Aggressiveness}

Independent commissioners play an important role as supervisors and directors for company operations to comply with the applicable regulations. Tax-related decisions are an important tool for independent commissioners to mediate between company management and company owners in planning their strategies and policies in order not to violate the applicable regulations. In addition, independent commissioners have the functions as a counterweight to decision making in order to protect small shareholders and related parties. The existence of independent commissioners is expected to further strengthen management supervision to prevent companies from engaging in fraudulent practices, such as tax aggressiveness (Suyanto \& Supramono, 2012). Christiana \& Africano (2017) have conducted a study and found that aggressiveness can be negatively influenced by the proportion of the independent board of commissioners. The large number of independent commissioners is good evidence in the supervision of independent company 
management so that the company does not perform tax aggressiveness. Based on the description above, the hypothesis can be formulated as follows:

$H_{4}: \quad$ Independent Board of commissioners has a positive effect on tax aggressiveness

\section{Audit Committee and Tax Aggressiveness}

The audit committee has the function to have a significant effect on the determination of company policy, and with the authority, the audit committee has to try to prevent the deviant actions regarding to the financial reports. Tight supervision makes the quality of information and performance provided better and more effective (Diantari \& Ulupui, 2016). The expertise possessed by the audit committee regarding to the financial and accounting reports, both in the use of certain accounting methods and ways to avoid risks, enable the companies to be monitored and controlled so that they have no tax aggressiveness.

Maharani \& Suardana (2014) and Diantari \& Ulupui (2016) have conducted the research finding that tax avoidance can be negatively influenced by the audit committee. The differences in audit committee lead the company responsible and open in the presentation of their financial statements. The Audit Committee well performed the monitoring function. Based on the description above, the hypothesis can be formulated as follows:

$H_{5}$ : Audit Committee has a positive effect on tax aggressiveness

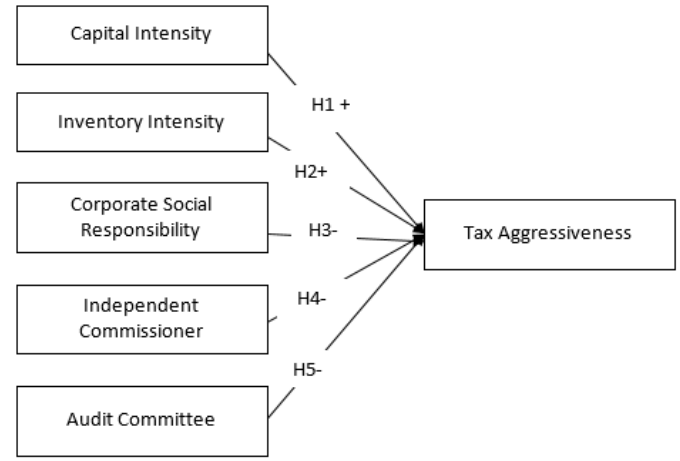

Figure 1. Research Framework 


\section{Research Methods}

The population of this study was manufacturing companies listed on the Indonesia Stock Exchange within the period of 2016 - 2018. The samples in this study were determined using a purposive sampling technique using the predetermined criteria. The samples were determined based on the following criteria: (1) Companies registered and published a complete annual report from 2016-2018, (2) Using rupiah currency and (3) Performing the CSR disclosure.

The data collection methods in this study were documentation and literature study. Documentation is a method of collecting data by paying attention, using and observing the obtained data, while literature study is a method performed by studying the literatures, journals and other sources. The data were processed and analyzed using a multiple linear regression analysis technique equipped with the SPSS software.

Table 1. Variables, Definition and Operational Variables and Indicators

\begin{tabular}{|c|c|c|c|}
\hline No. & Variable & $\begin{array}{l}\text { Operational } \\
\text { Definition }\end{array}$ & Indicator \\
\hline \multirow[t]{2}{*}{1} & \multirow[t]{2}{*}{$\begin{array}{l}\text { Tax } \\
\text { aggressiveness }\end{array}$} & \multirow{2}{*}{$\begin{array}{l}\text { Activities in } \\
\text { minimizing } \\
\text { tax expense } \\
\text { legally and } \\
\text { illegally }\end{array}$} & Total Tax Income Expense \\
\hline & & & $\begin{array}{c}\text { Earning before tax } \\
\text { (Lanis and Richardson , 2012) }\end{array}$ \\
\hline \multirow[t]{2}{*}{2} & \multirow[t]{2}{*}{$\begin{array}{l}\text { Capital } \\
\text { Intensity }\end{array}$} & \multirow{2}{*}{$\begin{array}{l}\text { Ratio } \\
\text { between total } \\
\text { fix asset and } \\
\text { total asset }\end{array}$} & $\begin{array}{c}\text { Capital Intensity } \\
\text { Total Permanent Asset }\end{array}$ \\
\hline & & & $\begin{array}{c}\text { Total Asset } \\
\text { (Gemilang, 2016) }\end{array}$ \\
\hline \multirow[t]{2}{*}{3} & \multirow[t]{2}{*}{$\begin{array}{l}\text { Inventory } \\
\text { Intensity }\end{array}$} & \multirow{2}{*}{$\begin{array}{l}\text { Inventory } \\
\text { invested in } \\
\text { company } \\
\text { (comparison } \\
\text { between } \\
\text { inventory and } \\
\text { total asset) } \\
\end{array}$} & $\begin{array}{l}\text { Inventory Intensity } \\
\text { Total Supply }\end{array}$ \\
\hline & & & $\begin{array}{c}\text { Total Asset } \\
\text { (Herry, 2016) }\end{array}$ \\
\hline 4 & $\begin{array}{l}\text { Corporate } \\
\text { Social }\end{array}$ & $\begin{array}{l}\text { The } \\
\text { responsibility }\end{array}$ & CSRIi $=\frac{\sum X y i}{n i}$ \\
\hline
\end{tabular}




\begin{tabular}{|c|c|c|c|}
\hline & Responsibility & $\begin{array}{l}\text { of the } \\
\text { company to } \\
\text { the society }\end{array}$ & $\begin{array}{l}\text { Description: } \\
\text { CSRli : CSR index } \\
\sum \text { Xyi : disclosure item } \\
\mathrm{Ni}: \text { disclosed item } \\
\text { (Sulistyowati and Ulfah, 2018) }\end{array}$ \\
\hline \multirow[t]{2}{*}{5} & $\begin{array}{l}\text { Independent } \\
\text { Board of } \\
\text { commissioners }\end{array}$ & $\begin{array}{l}\text { Committee } \\
\text { which is } \\
\text { independent }\end{array}$ & $\begin{array}{l}\text { Independent committee Proportion } \\
\text { Number of Independent commissioners }\end{array}$ \\
\hline & & & $\begin{array}{c}\text { Number of Board of other Commissioners } \\
\text { (Maharani and Suardana, 2014) }\end{array}$ \\
\hline 6 & $\begin{array}{l}\text { Audit } \\
\text { Committee }\end{array}$ & $\begin{array}{l}\text { Committee } \\
\text { which has the } \\
\text { task to ensure } \\
\text { the financial } \\
\text { reporting }\end{array}$ & $\begin{array}{c}\text { Audit Committee } \\
=\sum \text { members of Audit committee in company } \\
\text { (Dewi, 2007) }\end{array}$ \\
\hline
\end{tabular}

Source: processed data, 2020

\section{Results and Discussion}

This research was conducted on the manufacturing companies listed on the Indonesian Stock Exchange (IDX) within a period of 2016-2018. The samples of this study were determined using a purposive sampling technique. The sampling processes were described in table 2 below.

\section{Table 2. Research Samples}

\begin{tabular}{lr}
\hline Sampling Criteria & Amount \\
\hline Companies Listed on IDX within 2016-2018 & 426 \\
Companies that did'nt provide complete annual report & 20 \\
Companies that did'nt use IDR & 27 \\
Companies that report losses in their annual report & 30 \\
Companies that did'nt provide complete data related to research & 6 \\
variable & 59 \\
Sample (1 periood) & 177 \\
Total Sample (3 period) & 66 \\
Outlier & 111 \\
Number Of Sample used &
\end{tabular}


Hani Werdi Apriyanti, Muhamad Arifin

Table 3. Descriptive Statistics

\begin{tabular}{llccccc}
\hline & N & Minimum & Maximum & Mean & $\begin{array}{c}\text { Std. } \\
\text { Deviation }\end{array}$ \\
\cline { 2 - 7 } JIAFR | 40 & Capital Intensity & 111 & 0.0914 & 0.7615 & 0.43623 & 0.1618 \\
& Inventory Intensity & 111 & 0.011 & 0.5964 & 0.20628 & 0.11834 \\
& CSR & 111 & 0.011 & 0.3187 & 0.12236 & 0.07335 \\
& Independent & 111 & 0.25 & 0.67 & 0.39874 & 0.0911 \\
& Commissioners & & & & 3.02703 & 0.1629 \\
& Audit Committee & 111 & 3 & 4 & 0.2546 & 0.02422 \\
& Tax Aggressiveness & 111 & 0.2043 & 0.3337 & & \\
& Valid N (Listwise) & 111 & & & &
\end{tabular}

Capital intensity has an average value of 0.436229 which means that on average the company has total fixed assets of $43.62 \%$ of the total company assets. The smallest value is 0.0914 , while the largest value is 0.7615 and the standard deviation is 0.1618 .

Inventory intensity standard deviation is 0.1183429 , with an average of 0.206283 meaning that the company has a total inventory of $20.62 \%$ of the total company assets. The minimum value is 0.0110 and the maximum value is 0.5964 .

The standard deviation for corporate social responsibility is 0.0733506 and the mean value is 0.122364 , meaning that the average of 111 companies discloses by $12.23 \%$ of items from the specified items of 91 items. The lowest value is 0.0110 and the highest value is 0.3187 . The standard deviation for the independent board of commissioners is 0.0910955 and the mean value is 0.398739 (39.87\%), which means that out of 111 companies have met the proportion of independent commissioners according to the minimum requirement. The minimum value is 0.2500 and the maximum value for the proportion of independent commissioners is 0.6700 .

The standard deviation of the audit committee is 0.1628976, the minimum value is 3.0000 , and the highest value is 4,000 . The average audit committee is 3.027027 meaning that the company has complied with the stipulated regulations. According to the Financial Services Authority Number 
55/POJK.04/2015 of 2015, audit committee can be interpreted as a committee which members are at least 3 members and have the task of helping the board independent commissioner.

The standard deviation for tax aggressiveness is 0.0242231 and the average value is 0.254601 , which means that the company has a total income tax expense of $25.46 \%$ of the total profit before tax. The smallest yield is 0.2041 the largest is 0.3337 .

Based on table 4, the test has resulted the data with a significance value of 0.200 , meaning that the data is said to be normal because the sig is $0.200>\alpha=$ 0.05 . Based on table 5, the test resulted in data with a VIF value of $<10$ and a tolerance value of $>0.10$, meaning that there is no multicollinearity between the independent variables. Based table 6 , the test results in data with the Durbin-Watson value of 2.2530 and the number of data $(\mathrm{n})=111$, and $\mathrm{k}=5$ ( $\mathrm{k}$ is the number of independent variables), the $\mathrm{dL}$ value is 1.6355, $\mathrm{dU}$ 1.7463, 4-DL, 4-DU 2, 2537. Because DU (1.7463) <DW (2.2530) <4-DU (2.2537), there is no auto correlation. Based on table 7 , the test results in a significance value of $>0.05$, meaning that the regression model has no heteroscedasticity.

Table 4. Normality Test Results

\begin{tabular}{llr}
\hline \multicolumn{2}{c}{ One-Sample Kolmogorov-Smirnov Test } \\
\hline \multirow{N}{*}{ Normal Parameters ${ }^{a, b}$} & Mean & Unstandardized Residual \\
& Std. Deviation & 111 \\
Most Extreme Differences & Absolute & 0.0229782 \\
& Positive & 0.067 \\
Test Statistics & Negative & 0.067 \\
Asymp. Sig. (2-tailed) & & -0.027 \\
& & 0.067 \\
\hline
\end{tabular}

Source: processed data, 2020 
Hani Werdi Apriyanti, Muhamad Arifin

Table 5. Multicollinearity Test Result

\begin{tabular}{llrr}
\hline \multicolumn{2}{c}{ Coefficients $^{\mathrm{a}}$} & & \\
\hline Model & & \multicolumn{2}{c}{ Collinearity Statistics } \\
& & Tolerance & VIF \\
& & 0.716 & 1.397 \\
& Capital Intensity & 0.735 & 1.36 \\
& Inventory Intensity & 0.977 & 1.023 \\
& CSR & 0.97 & 1.031 \\
& Independent & & 1.08 \\
& Commissioners & 0.921 & \\
& Audit Committee & & \\
\hline
\end{tabular}

Source: processed data, 2020

Table 6. Autocorrelation Test Results

\begin{tabular}{rccccc}
\hline Model & $\mathrm{R}$ & R Square & $\begin{array}{c}\text { Adjusted R } \\
\text { Square }\end{array}$ & $\begin{array}{c}\text { Estimated Std. } \\
\text { Error }\end{array}$ & $\begin{array}{c}\text { Durbin- } \\
\text { Watson }\end{array}$ \\
\hline 1 & $.316^{\mathrm{a}}$ & 0.1 & 0.057 & 0.02352 & 2.253 \\
\hline
\end{tabular}

Source: processed data, 2020

Table 7. Heteroscedasticity Test Results

\begin{tabular}{|c|c|c|c|c|c|c|}
\hline \multicolumn{7}{|c|}{ Coefficients $^{a}$} \\
\hline \multirow{2}{*}{\multicolumn{2}{|c|}{ Model }} & \multicolumn{2}{|c|}{$\begin{array}{l}\text { Unstandardized } \\
\text { Coefficients }\end{array}$} & \multirow{2}{*}{$\begin{array}{l}\text { Standardized } \\
\text { Coefficients } \\
\text { Beta }\end{array}$} & \multirow[t]{2}{*}{$\mathrm{T}$} & \multirow[t]{2}{*}{ Sig. } \\
\hline & & B & Std. Error & & & \\
\hline \multirow[t]{6}{*}{1} & (Constant) & 0.052 & 0.028 & & 1.87 & 0.064 \\
\hline & Capital Intensity & 0.014 & 0.01 & 0.16 & 1.456 & 0.148 \\
\hline & Inventory Intensity & -0.02 & 0.013 & -0.131 & -1.209 & 0.229 \\
\hline & CSR & 0.02 & 0.018 & 0.102 & 1.084 & 0.281 \\
\hline & $\begin{array}{l}\text { Independent } \\
\text { Commissioners }\end{array}$ & -0.02 & 0.015 & -0.145 & -1.539 & 0.127 \\
\hline & Audit Committee & -0.01 & 0.009 & -0.114 & -1.184 & 0.239 \\
\hline
\end{tabular}

Source: processed data, 2020 
Table 8. T test Results

\begin{tabular}{rlrrrrr}
\hline \multirow{2}{*}{ Model } & & \multicolumn{2}{c}{$\begin{array}{c}\text { Unstandardized } \\
\text { Coefficients }\end{array}$} & $\begin{array}{c}\text { Standardized } \\
\text { Coefficients }\end{array}$ & \multicolumn{1}{c}{ T } & \multicolumn{1}{c}{ Sig. } \\
\hline \multirow{2}{*}{1} & B & Std. Error & \multicolumn{1}{c}{ Beta } & & \\
& (Constant) & 0.34 & 0.047 & & 7.258 & 0 \\
& Capital Intensity & 0.028 & 0.016 & 0.189 & 1.73 & 0.087 \\
& Inventory Intensity & 0.001 & 0.022 & 0.006 & 0.052 & 0.959 \\
& CSR & 0.05 & 0.031 & 0.151 & 1.617 & 0.109 \\
& Independent & 0.004 & 0.025 & 0.014 & 0.144 & 0.886 \\
& Commissioners & & & & & \\
& Audit Committee & -0.035 & 0.014 & -0.235 & -2.441 & 0.016 \\
\hline
\end{tabular}

JIAFR | 43

Source: processed data, 2020

\section{The Effect of Capital Intensity on Tax Aggressiveness}

The test results show a positive direction which is equal to 0.028 while $t$ count of 1.73 with a significance value of $0.087>0.05$, meaning that $\mathrm{H} 0$ is accepted, while Ha1 is rejected. Thus, it can be concluded that Ha1 in which capital intensity has positive and significant effect on tax aggressiveness is rejected.

\section{The Effect of Inventory Intensity on Tax Aggressiveness}

The test results show a positive direction which is equal to 0.001 while $t$ count is 0.052 with a significance value of $0.959>0.05$, meaning that $\mathrm{H} 0$ is accepted while $\mathrm{Ha} 2$ is rejected. Thus, it can be concluded that Ha2 in which inventory intensity has a positive effect on tax aggressiveness is rejected.

\section{The Effect of Corporate Social Responsibility on Tax Aggressiveness}

The test results show a positive direction by 0.05 and t count by 1.617 with a significance value of 0.109 greater $(>)$ than 0.05 , meaning that $\mathrm{H} 0$ is accepted while Ha3 is rejected. Thus, it can be concluded that Ha3 in which corporate social responsibility which negatively and significantly effect on tax aggressiveness is rejected. 
Hani Werdi Apriyanti, Muhamad Arifin

\section{The Effect of Independent Commissioners on Tax Aggressiveness}

The test results show a positive direction by 0.004 and $t$ count by 0.144 with a significance value of $0.886>0.05$, meaning that $\mathrm{H} 0$ is accepted while JIAFR | 44 Ha4 is rejected. Thus, it can be concluded that Ha4 in which independent commissioner which has a negative effect on tax aggressiveness is rejected.

\section{The Effect of Audit Committee on Tax Aggressiveness}

The test results show a negative direction which is equal to -0.035 while $t$ count is -2.441 with a significance value of $0.016<0.05$, meaning that $\mathrm{H} 0$ is rejected while $\mathrm{Ha} 5$ is accepted. Thus, it can be concluded that Ha5 in which audit committee which has a negative but significant effect on the tax aggressiveness is accepted.

\section{The Effect of Capital Intensity of Tax Aggressiveness}

The results show a positive direction, although the direction is positive but not significant, because the company manages the fixed assets not to reduce the taxes but used for the company's production activities.

It can be assumed that the fixed assets are not used for tax avoidance purposes (not a tax aggressive form). The results are in accordance with the study conducted by Chiou et al. (2012), Haryadi (2012), and Adisamarta \& Noviari (2015) proving that many fixed assets are not used by the companies to avoid taxes but used for the company operational activities. Meanwhile, Hanum (2018) and Andhari \& Sukartha (2017) have provided evidence related to the significant effect of fixed assets on tax avoidance because the incident of depreciation costs can reduce the tax expenses.

\section{The Effect of Inventory Intensity on Tax Aggressiveness}

The results show a positive direction but not significant. The company has provisions, which will be used in accordance with its function to facilitate the company's production so that it runs in the long term without a shortage of raw materials. In the manufacturing companies, the inventory of the owned raw materials tends to be large because in the manufacturing 
companies, the raw materials are managed into the finished goods. Therefore, in this study, although the direction is positive, it is not significant because the manufacturing companies have a lot of inventory for the company's production activities.

The results of this study support those of research conducted by Hidayat JIAFR | 45 and Fitria (2018) as well as Andhari and Sukartha (2017) resulting in a statement that inventory intensity has a positive but not significant effect on tax aggressiveness. The results of this study are also different from those of research conducted by Adisamarta \& Noviari (2015) stating that inventory intensity has a positive and significant effect on tax aggressiveness.

\section{The Effect of Corporate Social Responsibility [CSR] on Tax Aggressiveness}

The results show that there is a positive but insignificant direction, meaning that tax aggressiveness cannot be influenced by CSR. The level of CSR performed by the company cannot affect the level of tax aggressiveness in the companies used as samples in this research. Corporate social responsibility only revealed the average of 0.122364 , meaning that the revealed average was only $12.23 \%$ or 11 of 91 specified items.

According to the obtained results, this study is in accordance with those of research conducted by Noviyanti (2017) and Abidin et al. (2018) stating that there is no significant affect related to corporate social responsibility on tax avoidance.

\section{The Effect of Independent Commissioners on Tax Aggressiveness}

The data show that there is no significant positive effect between independent commissioners on tax aggressiveness. The size of the number of independent commissioners has not been able to reduce tax aggressiveness. Independent commissioners as controllers of company performance in optimizing company value in reducing tax aggressiveness are still ineffective. The existence of an independent commissioner in corporate governance has not been followed by the functions and duties of a good supervisor in the 
supervision and direction of financial reporting activities, including tax avoidance activities.

As for the research that supports the results of this research, namely research conducted by Khaoula and Ali (2012), Abidin et al. (2018) results in a statement that there is no significant effect between independent commissioners on tax aggressiveness.

\section{The Effect of Audit Committee on Tax Aggressiveness}

Based on the analysis results, it shows that the audit committee has a negative but significant effect on tax aggressiveness, meaning that the presence of audit committee in corporate governance is considered capable of reducing the tax aggressiveness. The audit committee has performed its authority properly in preventing the deviant actions contained in the financial reports. The audit committee is able to perform its functions and duties in assisting the board of commissioners in supervising and directing management in controlling the company, through the accurate reporting not by doing the tax evasion.

The results of this study were supported by the previous researchers, including the research conducted by Asri \& Ketut (2016), Maharani \& Suardana (2014), and Diantari \& Ulupui (2016) resulting in a statement that there was a negative but significant effect of audit committee on tax aggressiveness.

\section{Conclusion}

Capital intensity affects tax aggressiveness in a positive and insignificant direction. Tax aggressiveness increases when capital intensity increases, but it is not significant because the company uses its fixed assets for the operational purposes not to reduce the tax burden. Inventory intensity affects tax aggressiveness in a positive and insignificant direction. Tax aggressiveness increases, when inventory intensity is high, but the increase is not significant because the company uses inventory for operations. Corporate social responsibility affects tax aggressiveness in positive but insignificant 
direction. The average of company samples in performing responsibilities is still low by $12.23 \%$. Therefore, the CSR activities of the companies taken as the research samples cannot reduce the level of tax aggressiveness. The independent board of commissioners affects tax aggressiveness in a positive and insignificant direction. The size of independent commissioners cannot reduce tax aggressiveness. Independent commissioners as the controllers of company performance in reducing tax aggressiveness are still ineffective. The audit committee affects tax aggressiveness in negative but significant direction, yet the audit committee can reduce tax aggressiveness. The audit committee exercises its authority properly in preventing the tax aggressive actions.

The limitation of this study is that the ability of independent variable to influence the dependent variable is only 0.1 , which means that only $90 \%$ of tax aggressiveness variable is influenced by the other variables which are not examined in this study. To obtain better results, the research period can be extended and added with various types of sectors instead of manufacturing, such as finance, services or banking because the characteristics of each sector are different. Future studies can add other dependent variables which possibly affect tax aggressiveness, such as institutional ownership and managerial ownership.

\section{References}

Abidin, M. Z., Askandar, N. S., \& Afifudin. (2018). Pengaruh Good Corporate Governance dan Corporate Social Responsibility terhadap Tindakan Pajak Agresif. Jurnal Ilmiah Riset Akuntansi.

Adisamartha, I. B. P. F., \& Noviari, N. (2015). Pengaruh Likuiditas, Leverage, Intensitas Persediaan Dan Intensitas Aset Tetap pada Tingkat Agresivitas Wajib Pajak Badan. E-Jurnal Akuntansi Universitas Udayana, 13, 973-1000.

Agoes, S., \& Ardana, I. C. (2013). Etika Bisnis dan Profesi: Tantangan Membangun Manusia Seutuhnya. Jakarta: Salemba Empat. 
Hani Werdi Apriyanti, Muhamad Arifin

Arismajayanti, \& Jati, I. (2017). Influence Of Audit Committee, Committee Independence, Independence Commissioner, and Leverage On Tax. Journal Of Auditing, Finance and Forensic Accounting, 5(2).

Andhari, P. A. S., \& Sukartha, I. M. (2017). Pengaruh Pengungkapan Corporate JIAFR | 48 Social Responsibility, Profitabilitas, Inventory Intensity, Capital Intensity dan Leverage pada Agresivitas Pajak. E- Jurnal Akuntansi Universitas Udayana, 18, 2115-2142.

Asri, I. A. T. Y., \& Suardana, K. A. (2016). Pengaruh Proporsi Komisaris Independen, Komite Audit, Preferensi Risiko Eksekutif dan Ukuran Perusahaan pada Penghindaran Pajak.Jurnal Akuntansi. 16(1), 72-100.

Baker, M. (2003). Corporate Social Responsibility in 2003: A Review of the Year. www.mallenbaker.net. 3 Juli 2003.

Branco, M., \& Rodrigues, L. (2007). Positioning Stakeholder Theory within the Debate on Corporate Social Responsibility. Electronic Journal of Business Ethics and Organization Studies , 32, 5-15.

Chariri, A., \& Ghozali, I. (2007). Teori Akuntansi. Semarang: Universitas Diponegoro.

Christiana, \& Africano, F. (2017). Peran Corporate Governance sebagai Pemoderasi atas Pengaruh Agresivitas Pelaporan Keuangan terhadap Agresivitas Pajak (Studi Empiris Perusahaan Manufaktur yang terdaftar di Bursa Efek Indonesia Tahun 2012-2016). Jurnal Akuntansi, $1-20$.

Chiou, Y.C., Hsieh, Y.C., \& Lin, W. (2012). Determinants of Effect Tax Rates for Firm Listed on China`s Stock Markets: Panel Models with Two-Sided Censors. International Trade \& Academic Research Conference (ITARC). 7-8th November 2012.

Davis, A. K., Guenther, D. A., Krull, L. K., \& Williams, B. M. (2016). Do socially responsible firms pay more taxes? The Accounting Review, 91(1), 4768.

Deegan, C. (2004). Financial Accounting Theory. McGraw-Hill Book Company: Sydney.

Diantari, P. R., \& Ulupui, I. A. (2016). Pengaruh Komite Audit, Proporsi Komisaris, dan Proporsi Kepemilikan Institusioanal terhadap Tax Avoidance. E-Jurnal Akuntansi, 16, 702-732. 
Dwiyanti, I. A. I., \& Jati, I. K. (2019). Pengaruh Profitabilitas, Capital Intensity, dan Inventory Intensity Pada Penghindaran Pajak. Jurnal Ekonomi dan Bisnis Universitas Udayana. 27(3), 2302-8556.

Gray, R, Owen D., and Adams, C. 1996. Accounting and Accountability. Prentice Hall Europe.

Freise, A., Link, S., \& Mayer, S. (2008). Taxation and corporate governance The state of the art. In: Schon, W, Tax and Corporate Governance. Springer-Verlag, Berlin Heidelberg.

Huseynov, F., \& Bonnie, K. K. (2012). Tax avoidance, Tax Management and Corporate Social Responsibility. Journal of Corporate Finance, 18(6), 804-827.

Hidayat, A. T., \& Fitria, E. F. (2018). Pengaruh Capital Intensity, Inventory Intensity, Profitabilitas dan Leverage terhadap Agresivitas Pajak. ejournal.stiedewantara.

Hoi, C. K., Wu, Q., \& Zhang, H. (2013). Is corporate social responsibility (CSR) associated with tax avoidance? Evidence from irresponsible CSR activities. The Accounting Review, 88(6), 2025-2059.

Imelia, S. (2015). Analisis Faktor yang Mempengaruhi Manajemen Pajak dengan Indikator Tarif Pajak Efektif (ETR) pada Perusahaan LQ45 yang terdaftar dalam Bursa Efek Indonesia Tahun 2010-2012. Jurnal Fekon, 2(1), 1-15.

Jensen, M. C., \& Meckling, W. H. (1976). Theory of the Firm: Managerial. Journal of Financial Economics, 3, 305-360.

Jessica, \& Toly, A. A. (2014). Pengaruh Pengungkapan Corporate Social Responsibility terhadap Agresivitas Pajak. Tax \& Accounting Review, $4(1)$.

Kementerian Keuangan RI. (2018). http:/www.kemenkeu.com. Kementerian Keuangan Republik Indonesia.

Khaoula, A., \& Ali Z. M. (2012). The Board of Directors and the Corporate Tax Planning: Empirical Evidence from Tunisia. International Journal of Accounting and Financial Reporting. 2(2), 142-157.

Kuriah, H. L., \& Asyik, N. F. (2016). Pengaruh karakteristik perusahaan dan corporate social responsibility terhadap agresivitas pajak. Jurnal IImu dan Riset Akuntansi, 5(3), 1-19. 
Hani Werdi Apriyanti, Muhamad Arifin

Landolf, U. (2006). Tax and Corporarate Responsibility. International Tax Review 29, 6-9.

Lanis, R., \& Richardson, G. (2011). The Effect of Board Director Composition on Corporate Tax Aggressiveness. Journal of Accounting and Public

JIAFR | 50 Policy, 30(1), 50-70.

Lanis, R., \& Richardson, G. (2015). Is Corporate Social Responsibility Performance Associated with Tax Avoidance? Journal Business Ethics $127,439-457$.

Maharani, I. G. A. C., \& Suardana, K. A. (2014). Pengaruh Corporate Governance ,Profitabilitas dan Karakteristik Eksekutif pada Tax Avoidance Perusahaan Manufaktur. E-Jurnal Akuntansi Universitas Udayana, 9(2), 525-539.

Megarani, N., Warno, W., \& Fauzi, M. (2019). The effect of tax planning, company value, and leverage on income smoothing practices in companies listed on Jakarta Islamic Index. Journal of Islamic Accounting and Finance Research, 1(1), 139-162. doi:http://dx.doi.org/10.21580/jiafr.2019.1.1.3733

Midiastuty, P. P., Suranta, E., Indriani, R., \& Putri, S. I. (2016). Pengaruh Kepemilikan Pengendali dan Corporate Governance terhadap Tindakan Pajak Agresif. Simposium Nasional Akuntansi , 1-27.

Mustika. (2017). Pengaruh Corporate Social Responsibility, Ukuran Perusahaan, Profitabilitas, Leverage, Capital Intensity dan Kepemilikan Keluarga terhadap Agresivitas Pajak. JOM Fekon, 4(1) , 1886-1900.

Noviyanti, F., Anggra, E., \& Muttaqin , I. (2017). Pengaruh Pengungkapan Corporate Social Responsibility (CSR), Struktur Kepemilikan, Manajemen Laba, dan Leverage terhadap Agresivitas Pajak. e-journal Universitas Pancasakti.

Nugraha, N. B., \& Meiranto, W. (2015). Pengaruh Corporate Social Responsibility, Ukuran Perusahaan, Profitabilitas, Leverage dan Capital Intensity terhadap Agresivitas Pajak. Diponegoro Journal of Accounting, $4,1-14$.

Peraturan Otoritas Jasa Keuangan No.33/POJK.04/2014 Tentang Direksi dan Dewan Komisaris Emiten atau Perusahaan Publik.

Peraturan Otoritas Jasa Keuangan Nomor 55/POJK.04/2015. Tentang Pembentukan dan Pedoman Pelaksanaan Kerja Komite Audit. (Online). www.ojk.go.id/regulasi/peraturan-ojk/POJK-Nomor55.POJK.04.2015. 
Prasojo, P., \& Syarifah, L. (2020). Residents preferences associated with tax amnesty program predisposition.Journal of Islamic Accounting and Finance Research, 2(2), 209-228. doi:http://dx.doi.org/10.21580/jiafr.2020.2.2.6072

Putri. (2014). Pengaruh Likuiditas, Manajemen Laba dan Corporate Governance terhadap Agresivitas Pajak Perusahaan. Artikel.

Slemrod, J. (2004). The Economics of Corporate Selfiishness. Tax Journal, 57, 877-99.

Suyanto, K. D., \& Supramono. (2012). Likuiditas, Leverage, Komisaris Independen, dan Manajemen Laba terhadap Agresivitas Pajak Perusahaan. Jurnal Keuangan Dan Perbankan Universitas Kristen Satya Wacana, 16(2), 167-177.

Suryana. (2011). Kewirausahaan Pendoman Praktis. Jakarta: Salemba Empat.

Watson, L. (2011). Corporate social responsibility and tax aggressiveness: An examination of unrecognized tax benefits. Working Paper. The Pennsylvania State University.

Watson, L. (2015). Corporate social responsibility, tax avoidance, and earnings performance. The Journal of the American Taxation Association (JATA), 37(2), 1-21.

Yoehana, M, (2014). Analisis Pengaruh Corporate Social Responsbility Terhadap Agresivitas Pajak. Universitas Diponegoro.

Zeng, T. (2016). Corporate social responsibility, tax aggressiveness, and firm market value. Accounting Perspectives, 15(1), 7-30. 
JIAFR | 52 